\title{
Nauplius
}

The Journal of The

Brazilian Crustacean Society

This article is part of the tribute offered

by the Brazilian Crustacean Society

in memoriam of Michael Türkay

outstanding contribution to Carcinology

e-ISSN 2358-2936

www.scielo.br/nau

www.crustacea.org.br

Original Article

\section{A new species of stygobitic aeglid from lentic subterranean waters in southeastern Brazil, with an unusual morphological trait: short pleopods in adult males}

Sérgio Luiz de Siqueira Bueno ${ }^{1}$, Alexandre Lopes Camargo ${ }^{2}$ and Juliana Cristina Bertacini Moraes ${ }^{1}$

\author{
1 Department of Zoology, Institute of Biosciences (IB-USP), University of São Paulo. \\ Rua do Matão, n. 101. 05508-090 São Paulo, São Paulo, Brazil. \\ SLSB E-mail: sbueno@ib.usp.br \\ JCBM E-mail: jcbm@ib.usp.br \\ 2 Rua Dr. Curt, 218. 09862-040 São Bernardo, São Paulo, Brazil. \\ ALC E-mail: iscoticave@gmail.com \\ ZOOBANK http://zoobank.org/urn:lsid:zoobank.org:pub:C8F75057-B45F-44DA- \\ 9CE4-08519819B75B
}

\section{Abstract}

Aegla charon n. sp. is endemic to the "Lago Subterrâneo" cave from the Alto Ribeira karst region, southeastern Brazil. The most remarkable morphological trait observed in the new species was the presence of partially developed pair of uniramous pleopods $2-5$ in adult male specimens, whereas the absence of these pleonal appendages is the general condition in this sex in Aegla Leach, 1820. Some of the pleopods are even morphologically similar to those typically

CORRESPONDING AUTHOR Sérgio Luiz de Siqueira Bueno sbueno@ib.usp.br

SUBMITTED 21 February 2017 ACCEPTED 19 May 2017

PUBLISHED 22 June 2017

Guest Editor

Célio Magalhães

DOI 10.1590/2358-2936e2017021 observed in adult females in that they may also be two-segmented, only shorter in size. The pigmented area of the cornea is slightly reduced, which is probably a troglomorphic adaptation to subterranean habitats. Aegla charon n. sp. is also the only obligate cave-dwelling aeglid known to inhabit lentic subterranean waters. A key to all species from the Alto Ribeira karst area is provided.

\section{KEY WORDS}

Aeglidae, high endemism, pleonal appendages in males, subterranean lake. 


\section{INTRODUCTION}

Crustaceans dominate over other groups of invertebrates in aquatic subterranean habitats, both in number of species and distribution (Botosaneanu, 1986; Stoch, 1995; Sket, 1999; Culver and Sket, 2000; Christman and Culver, 2001). The highest diversity of stygobitic crustaceans is found in the copepods (Maxillopoda: Copepoda), amphipods and isopods (Malacostraca: Peracarida), which, in turn, are also quite common to marine and freshwater habitats in nonsubterranean environments. Stygobitic crustaceans even include taxa with representatives exclusively associated with underground freshwater habitats, such as the orders Gelyelloida (Copepoda), Bathynellacea (Syncarida), Thermosbaenacea, and Spelaeogriphacea (Peracarida) (Pires, 1987; Stoch, 1995). Among the Decapoda, the most familiar freshwater stygobitic representatives reported from several caves in the Americas and elsewhere around the world include caridean prawns, astacidean crayfishes and brachyuran crabs (Hobbs et al., 1977; Stoch, 1995; Mejía-Ortíz et al., 2003; 2008; Graening and Fenolio, 2005; Baldari et al., 2010; Villalobos and Álvarez, 2013; Marin and Sokolova, 2014; Cai and Vidthayanon, 2016).

Aegla Leach, 1820 is the only taxon of Anomura that is fully adapted to freshwater environments (Schmitt, 1942; Bond-Buckup and Buckup, 1994; Bueno et al., 2016). As of 2016, eighty-three nominal species and subspecies have been described (Moraes et al., 2016), all of them endemic to temperate and subtropical regions of continental South America (Bueno et al., 2016). Most aeglids inhabit epigean habitats; however, three species have been described as obligate cavedwellers (stygobites) from the Alto Ribeira karst region in southeastern Brazil: Aegla cavernicola Türkay, 1972, Aegla leptochela Bond-Buckup and Buckup, 1994, and Aegla microphthalma Bond-Buckup and Buckup, 1994. In the same karst area, Aegla strinatii Türkay, 1972, Aegla schmitti Hobbs III, 1978, and Aegla marginata Bond-Buckup \& Buckup, 1994 were the three other aeglid species reported to form stygophilic populations, which are capable of moving freely between the epigean and the subterranean worlds (Rocha and Bueno 2004; 2011; Fernandes et al., 2013; Maia et al., 2013).

This paper provides detailed morphological description of aeglid specimens sampled from "Lago Subterrâneo" cave (Portuguese for Subterranean
Lake), one of four stygobitic aeglid new material recently reported from the Alto Ribeira karst region by Fernandes et al. (2013); each of which with the potential for constituting a new species yet to be formally described.

\section{Material and Methods}

\section{Sampling area}

The "Lago Subterrâneo" cave is located in the Intervales State Park, district of Bulha d'Água, Guapiara county, state of São Paulo, southeastern Brazil (Fig. 1). The small cave entrance $\left(24^{\circ} 19^{\prime} 34.1^{\prime \prime} \mathrm{S} 48^{\circ} 29^{\prime} 24.4^{\prime \prime} \mathrm{W}\right)$ leads to a $200 \mathrm{~m}$-long subterranean labyrinthine system of descending tunnels and vertical walls before reaching the lake area about $30 \mathrm{~m}$ below ground level (Fig. 2). A small shallow riffle gently flows into the lake without disturbing the lentic characteristics of the latter (Fig. 3). The bottom of the lake is covered with fine loose clay deposit, which can be easily suspended towards the water column by man-made disturbance.

Specimens were either caught by hand after being visually spotted with flashlight or captured with baited traps set in shallow areas along the margins of the lake for a couple of hours (Fig. 4). Sampled specimens were kept separated from one another in perforated plastic bags, so as to prevent the loss of individual information should autotomy of the chelipeds or walking legs occur during the fixation procedure in $70 \%$ ethyl alcohol solution.

\section{Morphology and Morphometrics}

Description was based on the male holotype and morphological variations were based on the type series. Names and terminology used to describe body parts and appendages, with the exception of the first pair of pereopods, followed Schmitt (1942), Martin and Abele (1988), and Bond-Buckup and Buckup (1994) and Moraes et al. (2016). Terminology used to describe the morphology of the first pair of pereopods (chelipeds) followed Martin and Abele (1988) and Moraes et al. (2016), in which the relative position of margins and surfaces of segments with respect to the inward rotation of the appendage was observed. Major and minor chelipeds are described separately because they are unequal in size and show morphological differences between them, especially with regard to the three distalmost segments (carpi, propodi and dactyli). 


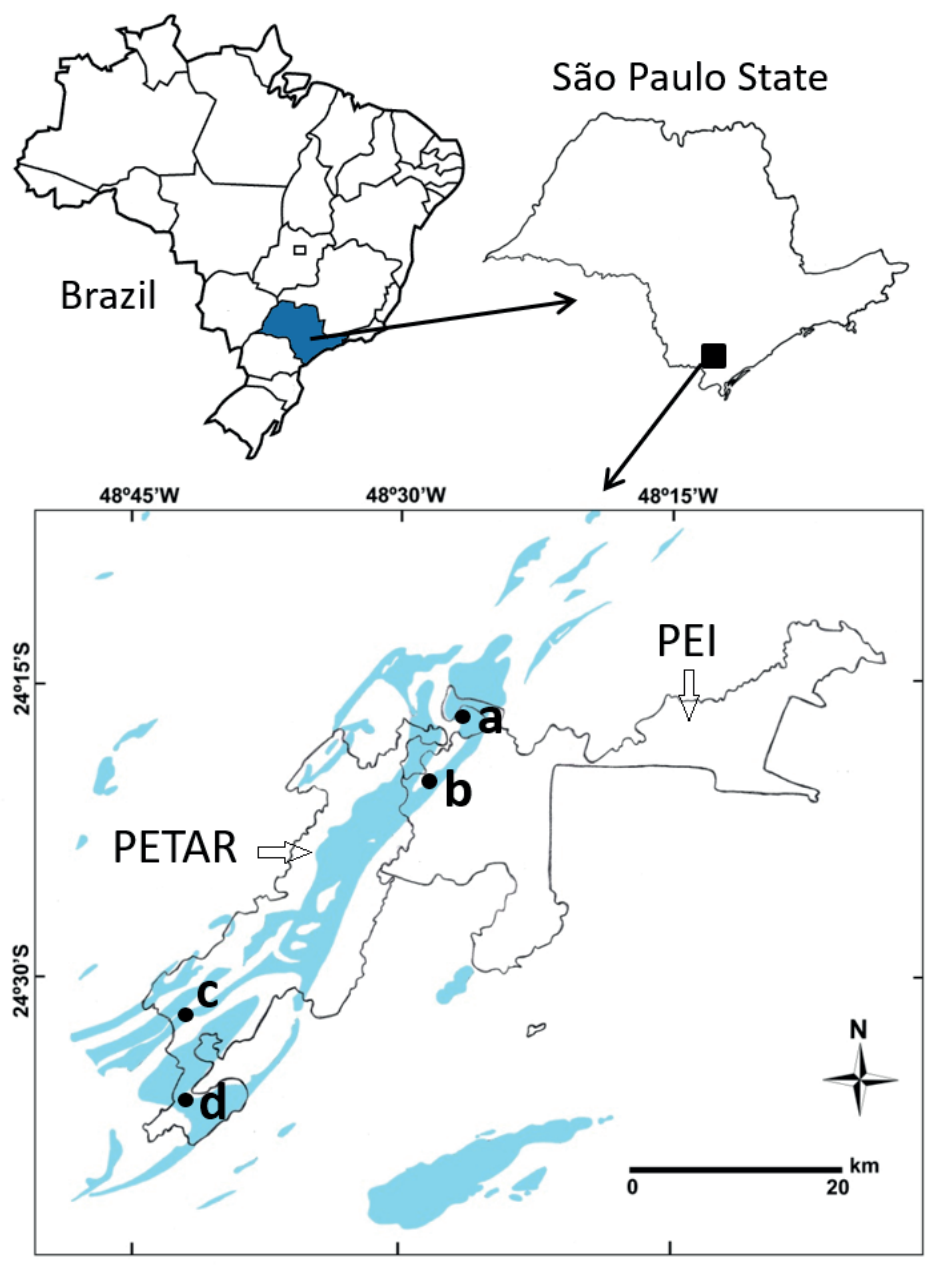

Figure 1. Map of the Alto Ribeira karst region (partial) in the state of São Paulo, Brazil, showing the border limits of the PETAR (Parque Estadual Turístico do Alto Ribeira) and Intervales State Park (PEI in Portuguese), and the corresponding type locality of the stygobitic aeglids: (a) Aegla leptochela and (b) A. charon n. sp. from Intervales, and (c) A. microphthalma and (d) A. cavernicola from PETAR. Light blue areas on map indicate distribution of limestone lenses. Modified from Fernandes et al. (2013).

All meristic data were taken with camera lucida attached to a dissecting scope, except carapace length dimensions (CL and CLR), which were taken with digital caliper to the nearest $0.01 \mathrm{~mm}$.

Carapace length (CL): distance between right orbital sinus midpoint (selected for standardization purpose) to posterior margin midpoint. An alternate carapace length measurement (CLR), taken from tip of rostrum to posterior margin midpoint, is also provided for comparison with other descriptive works where this dimension has been used instead. The size of the holotype and the range size of the type series, expressed as CL and CLR, are indicated in brackets in the "material examined" in the "results" section.

All measurements and calculation procedures for determining the shape of body parts or structures and appendage segments discriminated below are based on Moraes et al. (2016), except when noted.

Rostral base width (a): straight line distance between left and right orbital sinuses midpoints. Left lateral margin of rostrum (b) (selected for standardization purpose): straight-line distance taken from the apex of rostrum to the left orbital sinus midpoint. Based on the value obtained from the ratio $a / b$, three sizes of rostrum are recognized (modified from Moraes et al., 2016): long $(\mathrm{a} / \mathrm{b}<0.95$, resembling a narrow base isosceles triangle), regular $(0.95 \leq \mathrm{a} / \mathrm{b} \leq 1.05$, resembling an equilateral triangle), and short $(\mathrm{a} / \mathrm{b}>$ 1.05 , resembling a wide base isosceles triangle).

For determining the extension of the apex of anterolateral spines in relation to basal margin of 


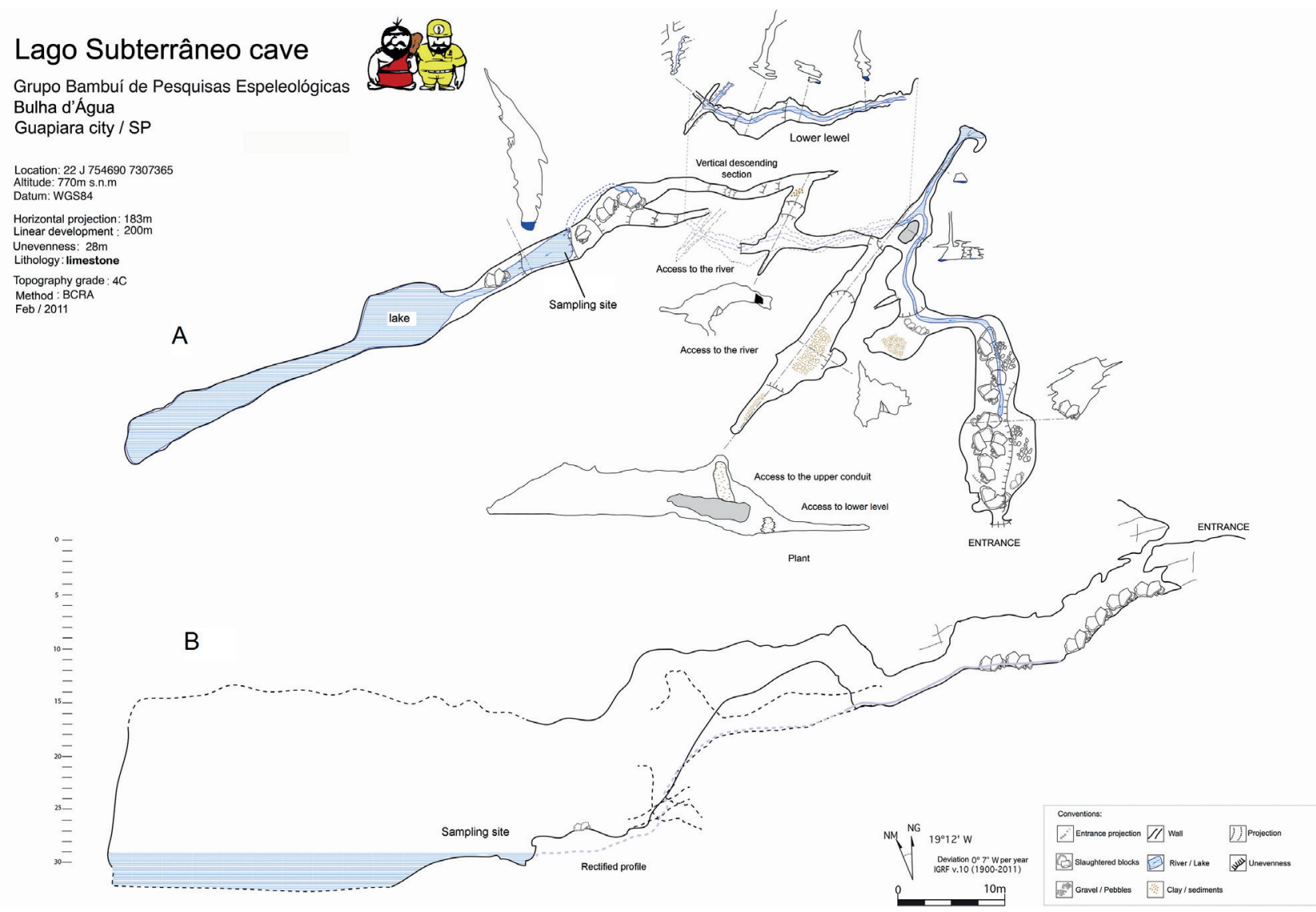

Figure 2. A, Floor plan; B, longitudinal section maps of "Lago Subterrâneo" cave, with indication of sampling site. This map was drawn and produced by Grupo Bambuí de Pesquisas Espeleológicas and used herein by kind permission.

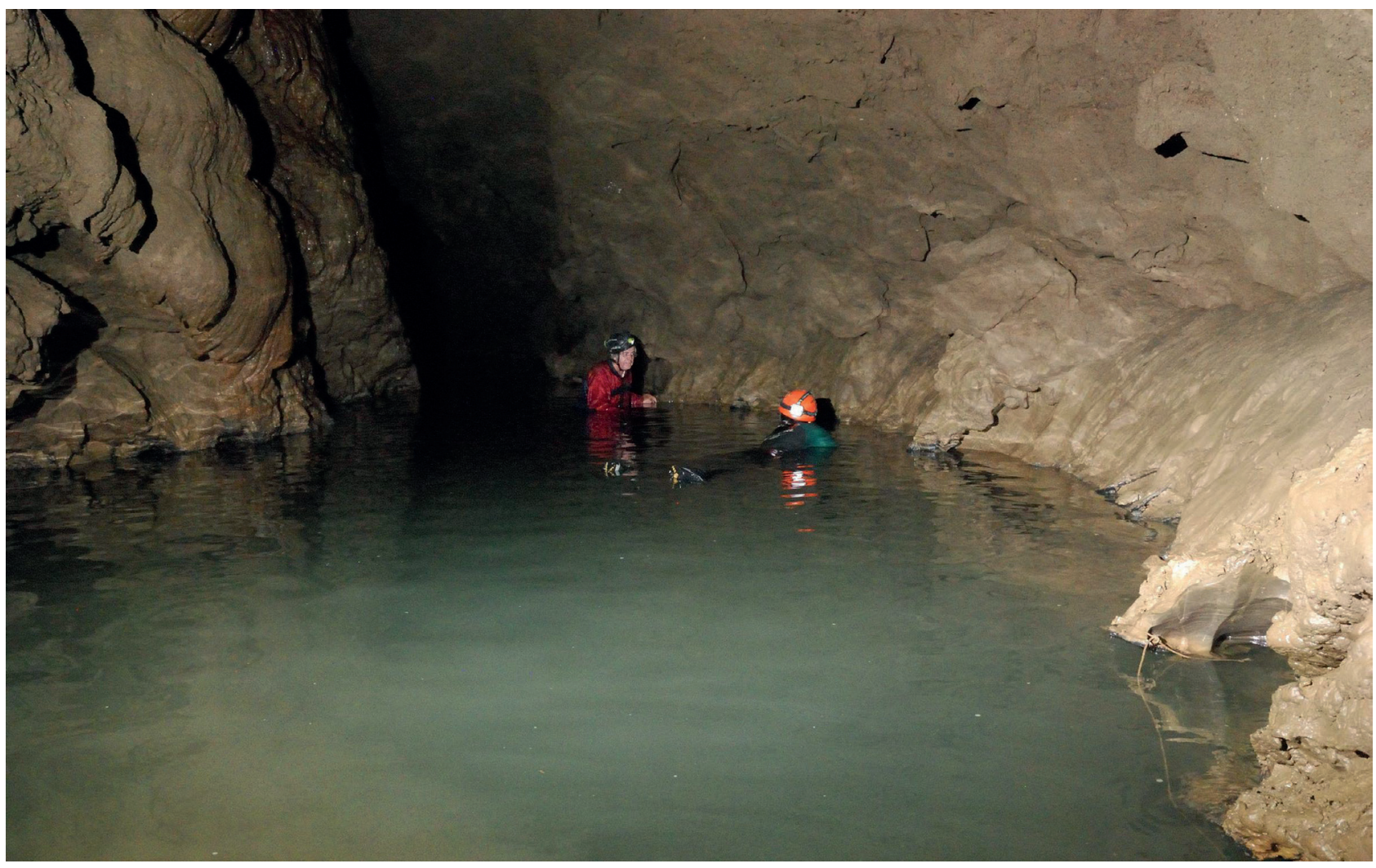

Figure 3. Visual search for aeglids in shallow areas near margins of the subterranean lake (partial view). Photo by Alexandre L. Camargo. 


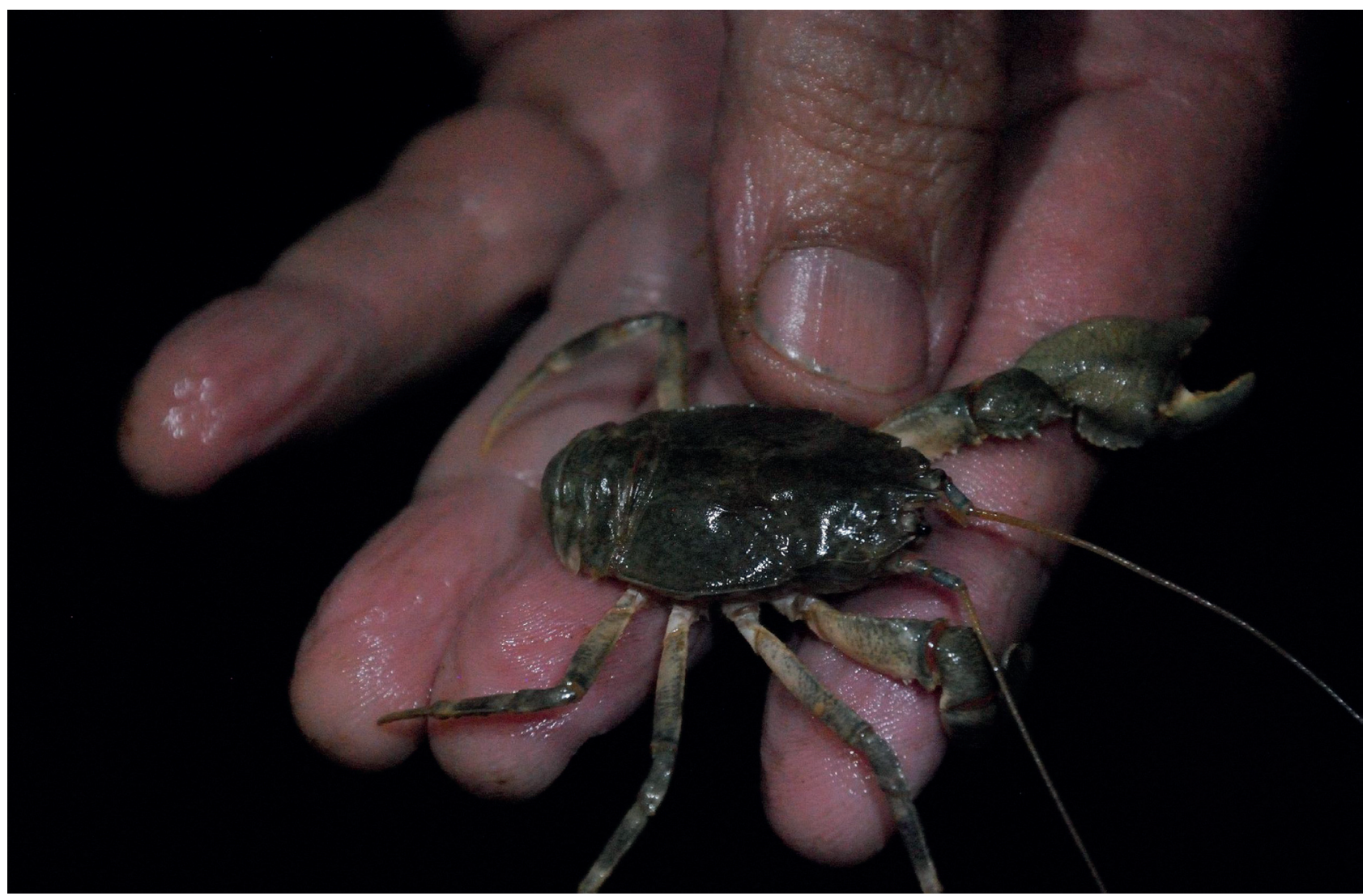

Figure 4. Live male specimen of Aegla charon n. sp. Photo by Alexandre L. Camargo.

cornea, the eyestalks were carefully kept in parallel alignment with rostral carina.

Shape of palmar crest was based on the angle formed between posterior margin of palmar crest and proximal dorsal margin of propodus near articulation with carpus: "rudimentary" when inflexion is smooth (angle markedly obtuse), "rectangular" when inflexion tends to orthogonal (slightly obtuse angle to right angle) and "disciform" when inflexion is convex (acute angle, due to convex shape of posterior margin of palmar crest).

Height of palm (with palmar crest excluded; Fig. 5A), determined as the ratio between length (a) (fixed finger excluded) and lower section (b) of the orthogonal line (origin at midpoint of base of palmar crest to ventral margin) with respect to length (a): high if $\mathrm{a} / \mathrm{b} \leq 4.5$; low if ratio $>4.5$.

Shape of cardiac area (Fig. 5B): ratio between anterior (a) and posterior (b) margins of cardiac area. Shape is "trapezoidal" when ratio $\geq 1.35$, or "subrectangular" when ratio $<1.35$.

Areolar shape (Fig. 5B): ratio between the areolar posterior margin (c) and the areolar anterior demarcation (d), the latter one measured as the distance between the centers of lateral terminal pits.
If ratio $\geq 1.7$, then shape is "trapezoidal". If less than 1.70 , calculate $\{h /[(c+d) / 2]\}$, where $(h)$ is the areolar height. The following shapes are then recognized: "rectangular" (> 2.30), "subrectangular" ( $>1.60$ to 2.30 ), or "subquadrate" (>1.00 to 1.60 ).

Shapes of the anteromesial sclerite of third thoracic sternite (tapered, truncate or abrupt) were based on descriptions and illustrations provided by Moraes et al. (2016).

Sexual tube (male specimens). Preparation of the fifth pereiopods for scanning electron microscopy (SEM) followed Moraes et al. (2016). Sexual tube observation followed standardized spatial orientation view as recommended by Moraes et al. (2016).

The width of the uropods was based on the ratio between maximum width of the endopod (a) and half the maximum width of telson (b), the latter measurement was taken from anterolateral margin to longitudinal suture [see Moraes et al. (2016) for details and figure]. The recognized shapes are: "wide", when $\mathrm{a} / \mathrm{b} \geq 1.00$, and "narrow" when $\mathrm{a} / \mathrm{b}<1.00$.

Line drawings were made with camera lucida mounted on a dissecting scope. All drawings and images 

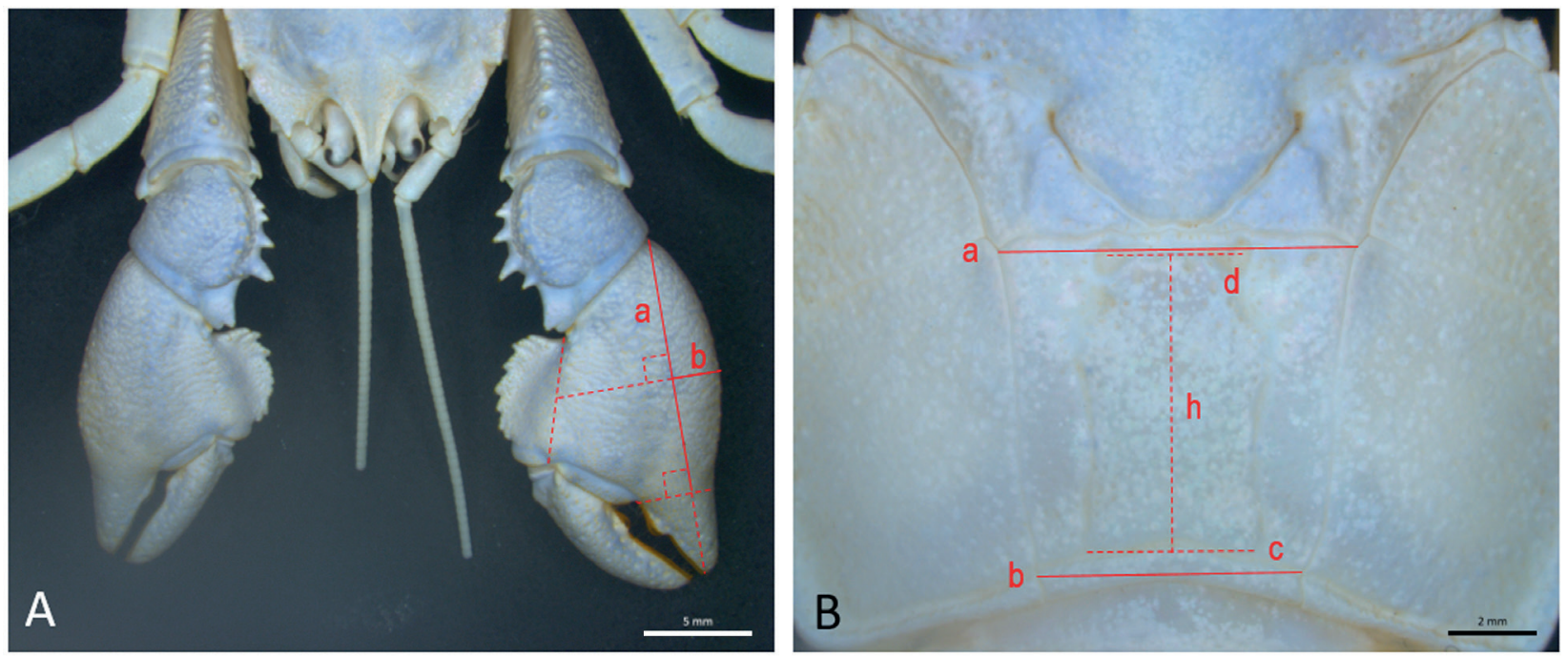

Figure 5. Measurements taken to calculate: A, height of palm of both major and minor chelae (solid lines a, b, as indicated on major chela); B, shapes of cardiac (solid lines a, b) and areolar (dashed lines c, d, h) areas. See "Materials and Methods" for details.

were digitized and treated with image editing software (Adobe Photoshop version 7.0.1).

Holotype and type series material are deposited in the Crustacean Collection of the Museum of Zoology, University of São Paulo (MZUSP) except for one female specimen from the type series material, which was deposited in the Crustacean Collection of the Department of Biology (CCDB) of the Faculdade de Filosofia, Ciências e Letras de Ribeirão Preto, University of São Paulo (FFCLRP-USP).

\section{TAXONOMY}

Family Aeglidae Dana, 1852

\section{Genus Aegla Leach, 1820}

\section{Aegla charon Bueno and Moraes n. sp.}

(Figs. 4, 6-11, 12C)

Material examined. Holotype: male [20.40 mm CL or $23.91 \mathrm{~mm}$ CLR], Brazil, Ribeira de Iguape Hydrographic Basin, Alto Ribeira karst region, state of São Paulo, county of Guapiara, Intervales State Park, Lago Subterrâneo cave (cave entrance: 2419'34.1'S 48²9'24.4”W), Sérgio L. S. Bueno, Adriana P. Bueno and Alexandre L. Camargo colls., 19.ii.2011 (MZUSP 35193). Paratypes: 2 males [18.11-20.57 mm CL; 21.46-23.95 mm CLR] and 3 females [15.67-18.01 $\mathrm{mm} \mathrm{CL} ; 18.88-21.65 \mathrm{~mm}$ CLR], same data as holotype
(MZUSP 35194); 1 male [15.91 mm CL; $19.20 \mathrm{~mm}$ CLR], 1 female [16.02 mm CL; $19.13 \mathrm{~mm}$ CLR], same data as holotype, except Alexandre L. Camargo coll., 18.xii.2010 (MZUSP 35195), 1 female [14.67 mm CL; $17.27 \mathrm{~mm} \mathrm{CLR],} \mathrm{same} \mathrm{data} \mathrm{as} \mathrm{holotype,} \mathrm{except}$ Alexandre L. Camargo coll., 18.xii.2010 (CCDB 6140).

Diagnosis. Pigmented area of cornea slightly reduced. Rostrum long with fringe of setae subventrally on mid- and proximal third of lateral margins. Tuft of setae behind shaped subrostral process. Anterolateral spine curved upward and not reaching basal margin of cornea. Cardiac area trapezoidal. Areolar area subrectangular. Partially developed uniramous, one- or two-segmented pairs of pleopods on pleonal somites 2-5 in adult male specimens. Posterolateral margin of telson concave mesially.

Description of the male holotype. Compound eyes: pigmented area of cornea slightly reduced (grade 1; see definition in the discussion section) as compared to epigean species, eyestalk well developed.

Anterior dorsal region of carapace (Figs. 6, 7A): rostrum long, narrow base triangular shaped (ratio $=0.94$ ), distal end slightly curved upward, apex overreaching distal end of cornea, lateral margins with row of corneous scales regularly distributed; fringe of long pappose setae evenly distributed subventrally on mid- and proximal third lateral margins of rostrum, 


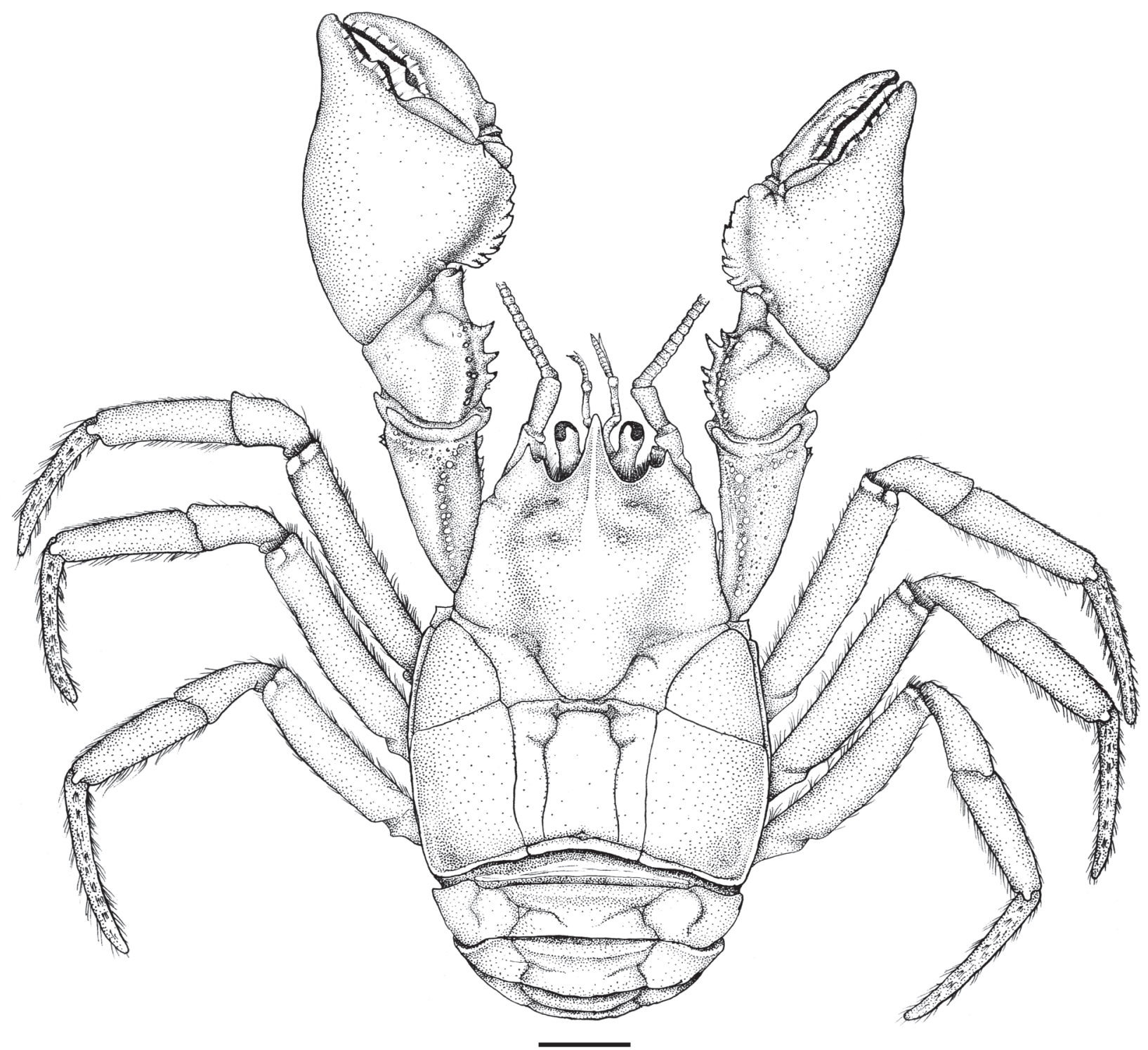

Figure 6. Aegla charon n. sp., male, holotype (CL $20.40 \mathrm{~mm}$; CLR $23.91 \mathrm{~mm})($ MZUSP 35193), dorsal view. Scale bar $=5.0 \mathrm{~mm}$.

and extending to margins of orbital and extraorbital sinuses as well. Rostral carina extending posteriorly to merge with general surface of carapace at level of protogastric lobes (in lateral view), reaching tip of rostrum anteriorly, elevated at mid-third, and punctuated with small scattered corneous scales. Sub-rostral process on proximal half of subrostral margin well developed, produced ventrally, triangular shaped, apex blunt, and with tuft of long pappose setae posteriorly. Orbital spine prominent, with spiny corneous tip; orbital and extraorbital sinuses well defined. Anterolateral spine acute, with cornified tip, curved upward (approx. $30^{\circ}$ ) and not reaching basal margin of cornea. Delimitation between posterior margin of anterolateral lobe and first hepatic lobe deeply demarcated, the latter tipped by blunt corneous scale at anterolateral angle. Lateral margin of the three hepatic lobes considered altogether and sequentially slightly concave in dorsal view and noticeably arcuate in lateral view, being more elevated at level of second hepatic lobe. Demarcation between first and second hepatic lobes weak, distinguishable as a small notch on lateral margin. Demarcation between second and third hepatic lobes rudimentary and noticeable as an incipient discontinuity on lateral margin. Dorsum of second hepatic lobe merging seamlessly with dorsum of gastric area. Epigastric prominences pronounced, round-shaped and ornamented with few corneous scales on summit. Protogastric lobes rudimentary, with few corneous scales on top. Posterior gastric pits 
not visible externally.

Posterior dorsal region of carapace (Fig. 6): Anterolateral region of epibranchial area slightly oriented upward, tipped by spiny corneous scale; anterior margin slightly concave; lateral margin straight, with corneous scales. Interior branchial area marked by elevated inner half area and depressed outer half area. Cardiac area trapezoidal (1.38). Areolar area sub-rectangular (1.93). Lateral margin of posterior branchial area with row of small corneous scales regularly distributed. Posterior margin devoid of corneous scales.

Third and fourth thoracic sternal plates (Fig. 7C). Third sternite: anteromesial margin abrupt, with two spiny corneous scales terminally. Fourth sternite: anteromesial region unarmed, with few long setae subdistally; anterolateral angles produced anteriorly, curved upward, and with apical corneous scale.

Chelipeds (first pair of pereopods) (Figs. 6, 7B). Unequal in size. Major cheliped. Dactylus (movable finger): dorsal margin and outer surface punctuated with small corneous scales, inner surface smooth; proximal lobe on dorsal margin with corneous scales; tufts of setae regularly distributed next to cutting margin on outer and inner surfaces; proximal third of cutting edge with wide lobular basal tooth covered by juxtaposed flat corneous scales of various sizes, the largest being the second distalmost one; remaining two-thirds of cutting edge with row of corneous scales changing width from wide proximally to narrow distally. Propodus: palm low (5.84), outer surface covered with corneous scales, longitudinal depression on upper section of proximal half near articulation with carpus; inner surface smooth, weakly excavated axially on lower-third section and accompanied by row of setal tufts; palmar crest rectangular, outer surface excavated, proximal half of dorsal margin with 4 tubercles tipped by spiny corneous scales, distal half lobulated, with row of corneous scales. Proximal third of cutting edge of fixed finger with wide lobular basal tooth covered by rows of juxtaposed flat corneous scales of various sizes; remaining two-thirds of cutting edge with row of corneous scales changing width from wide proximally to narrow distally; distal end with plate-like fused scales curved inward; tufts of simple setae distributed regularly along cutting margin on outer and inner surfaces of fixed finger. Carpus: dorsal margin with well-developed spiny subterminal lobe, and 3 spines decreasing in size proximally, and small tubercle devoid of corneous tip; subterminal lobe and spines on dorsal margin separated by large concave gap accompanied by 1 small, displaced spine next to carpal ridge; outer surface with carpal ridge adorned with groups of corneous scales and tiny setae regularly spaced; inner surface with three tubercles of unequal size near dorsal margin, accompanied by long simple setae, the distalmost tubercle being the largest one and surmounted by spiny corneous tip. Merus: dorsolateral edge adorned with row of low tubercles tipped by corneous scale, the distalmost one being the most developed; ventromesial edge with 6 tubercles gradually increasing in size distally, the distal one being the largest; ventrolateral border with 2 large tubercles subterminally near distal transverse groove followed by row of small tubercles proximally. Basi-ischium: dorsolateral edge with one heavy spine near articulation with merus; ventromesial edge with 5 spiny tubercles, the distalmost one being the largest; ventrolateral border smooth. Coxa: globose, unarmed.

Minor cheliped morphologically similar to major cheliped except as noted hereafter. Dactylus (movable finger): lobular basal tooth narrow covered by single row of spiny corneous scales; the remaining two-thirds of the cutting edge with row of narrow corneous scales. Propodus: inner surface excavated axially on both upper-third and lower-third sections, accompanied by tufts of simple setae, and producing an elevated area mesially ornamented by few tufts of simple setae; lobular basal tooth on proximal third of cutting edge of fixed finger rudimentary; cutting edge (lobular basal tooth included) with single row of narrow corneous scales. Carpus: dorsal margin with 5 spines, the largest being the second distalmost one; inner surface with 2 tubercles near dorsal margin, both surmounted by corneous tip. Merus: dorsolateral edge with one spine subdistally, followed by row of low tubercles tipped by corneous scale.

Second, third and fourth pairs of pereopods: morphologically similar, slender and laterally compressed. Row of spiny corneous scales regularly spaced along dorsal margin of dactyli, propodi, carpi and meri. General surface of dactyli covered with small pits from which tufts of simple setae sprout. Propodi with concentration of short simple setae on dorsal 

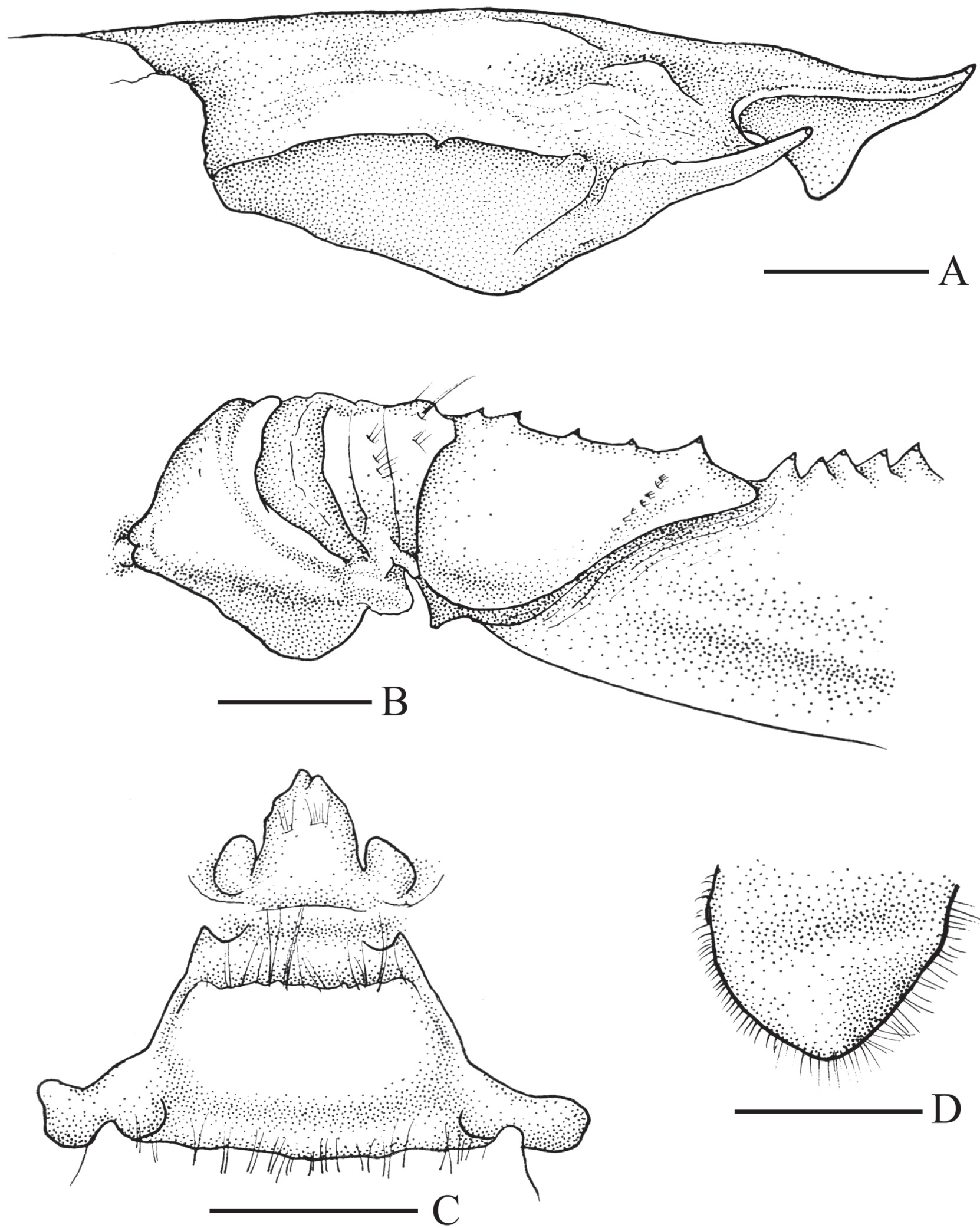

Figure 7. Aegla charon n. sp., male, holotype (MZUSP 35193). A) Lateral view of anterior region of carapace; B, Coxa, basi-ischium and merus (part); C, Third (in top position) and fourth sternites; D, Second pleonal epimeron. Scale bars $=2.5 \mathrm{~mm}$. 
margin and long simple setae on ventral margin. Carpi trapezoidal, with concentration of short simple setae on dorsal margin. Dorsal margin of meri predominantly covered with pappose setae on proximal half and simple setae on distal half. Basi-ischii with group of pappose setae on dorsal margin. Coxa globose.

Fifth pair of pereiopods. Reduced, segments cylindrical in cross section, except ischium (laterally compressed on proximal half), and dactylus (small, dorsally flattened, highly setose, and form minute chela with fixed finger of propodus). Propodus highly setose (fixed finger included). Carpus as long as propodus; setae more concentrated on distal third. Merus longer than carpus. Ischium slightly curved axially. Sexual tube long and narrow on coxa. [Fig. 8 shows sexual tube from the left fifth pereopods removed for SEM (Scanning Electron Microscopy) preparation from male paratype MZUSP 35194; CL $=20.57 \mathrm{~mm}$; CLR $=23.95 \mathrm{~mm}$, with similar morphology to the sexual tube of holotype.]

Pleonal epimera (D). Anterolateral angle of second epimeron and ventral angle of second, third and fourth epimera unarmed.

Pleopods. Partially developed, uniramous, oneor two-segmented. Second and third pairs, and left fourth pleopod one segmented, showing as conical buds. Right fourth and fifth pair two-segmented, about one-third as long as corresponding pleopods in adult female specimens; proximal segment longest, with concentration of long simple setae at distal end near articulation with distal segment. Distal segment short, slender, approximately one-fourth of the size of proximal segment and with long, simple setae concentrated distally. [Fig. 11 from male paratype, $20.57 \mathrm{~mm}$ CL; 23.95 mm CLR (MZUSP 35194)]

Uropods (Fig. 9). Biramous, wide (1.01), with fringe of long, plumose setae along free margins.

Telson (Fig. 9). Longitudinal suture well developed on dorsal surface, dividing the telson in two trapezoidal halves. Anterolateral margin with fringe of plumose setae on distal third; posterolateral margin concave mesially, with fringe of plumose setae which are longer terminally.

Variations. Cephalothoracic region. In all specimens examined of the type series, except the holotype, the subrostral process is subrectangular-shaped, slightly oriented anteriorly and with rounded apex in both sexes [Fig. 10, from male paratype; $18.11 \mathrm{~mm} \mathrm{CL;} 21.46$ mm CLR (MZUSP 35194)]. Other morphological variations observed in the type series are as follows: lateral margin of the hepatic lobes considered together straight (in dorsal view) and elevation may be incipient (in lateral view); anteromesial margin of third sternite truncate.

Chelipeds. Major chelipeds: tip of dactylus of major chela with inward plate-like fused scale (absent only in the holotype, possibly worn out or missing). Dorsal margin of palmar crest may be lobulate in its entirety, being formed by evenly distributed tubercles tipped by corneous scales. Number of spines on dorsal margin of carpus of major cheliped may vary from 3 to 5 , the largest one being either the first or the second distalmost one. Small displaced spine next to carpal ridge may be missing. Number of tubercles on inner surface of carpus may vary from 2 to 4 . Number of tubercles on ventromesial edge of merus may vary from 5 to 6 .

Pleon. Ventral angle of third and fourth pleonal epimera armed with one corneous scale each. Developmental stage of male pleopods 2-5 varies considerably, though none can be viewed as fully developed. Usually the $4^{\text {th }}$ and $5^{\text {th }}$ pairs are twosegmented, but similar morphological condition may be observed in the $2^{\text {nd }}$ and $3^{\text {rd }}$ pairs as well.

Females. Apart from the obvious sexually dimorphic condition with regard to the size of the first pair of chelipeds (they are smaller in females), the general morphology of this pair of appendages is similar in both sexes. In females, the elevation at middle-third section of rostral carina is less pronounced and uropods are narrower $(0.90 \pm 0.04 ; \mathrm{n}=5)$ than they are in males $(1.02 \pm 0.05 ; \mathrm{n}=4)$.

\section{Biology. Unknown.}

Etymology. From the Greek mythological character, Charon, the ferryman of the Underworld who was responsible for carrying the souls of the dead over the River Styx. Name by apposition.

Distribution. Restricted to the type locality: "Lago Subterrâneo" cave, in the state of São Paulo, southeastern Brazil. 


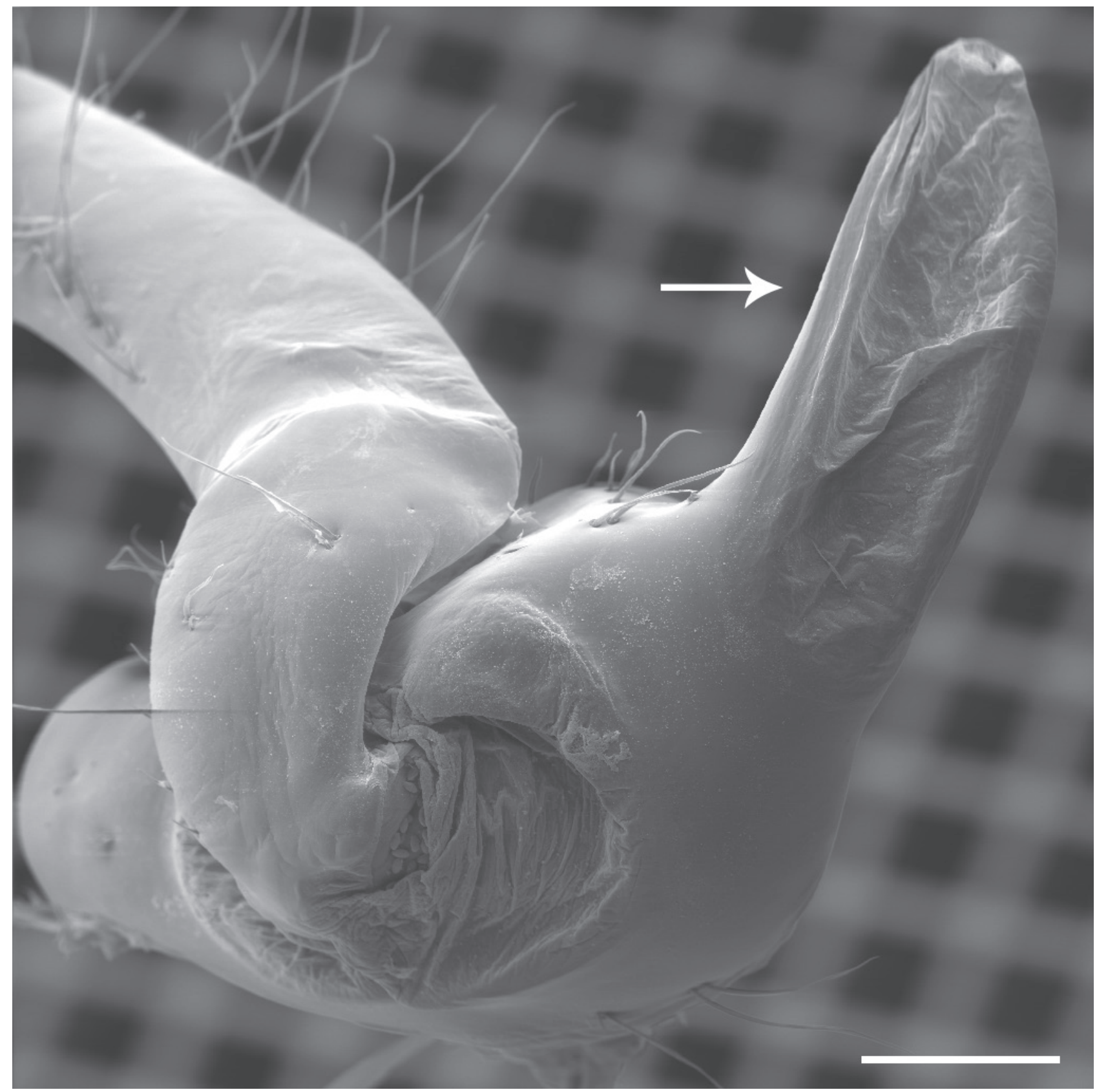

Figure 8. Aegla charon n. sp., male paratype (CL $20.57 \mathrm{~mm}$; CLR $23.95 \mathrm{~mm}$ ) (MZUSP 35194), sexual tube (arrow) on the coxa of the left fifth pereopods. Scale bar $=500 \mu \mathrm{m}$.

\section{DISCUSSION}

In Aegla, males and females lack the first pair of pleopods. Fully developed, uniramous, two-segmented pairs of pleopods $2-5$ are particular to female specimens, whereas in males these pairs of pleopods are absent or vestigial, usually resembling calcified knobs (Martin and Abele, 1988). This sexually dimorphic trait is frequently used for rapid sex determination of sampled specimens under fieldwork conditions (Bueno et al., 2016).
Adult males of $A$. charon n. sp., however, show an unusual morphological trait: pairs of short, partially developed pleopods $2-5$. Though the stages of development of these pleopods in males are considerably less pronounced than those observed in adult females, they cannot be viewed as absent or rudimentary as calcified knobs. A distinct twosegmented uniramous condition can even be observed, especially with regard to the fourth and fifth pairs of pleopods (Fig. 11; see also Fig. 2.6C in Bueno et al., 


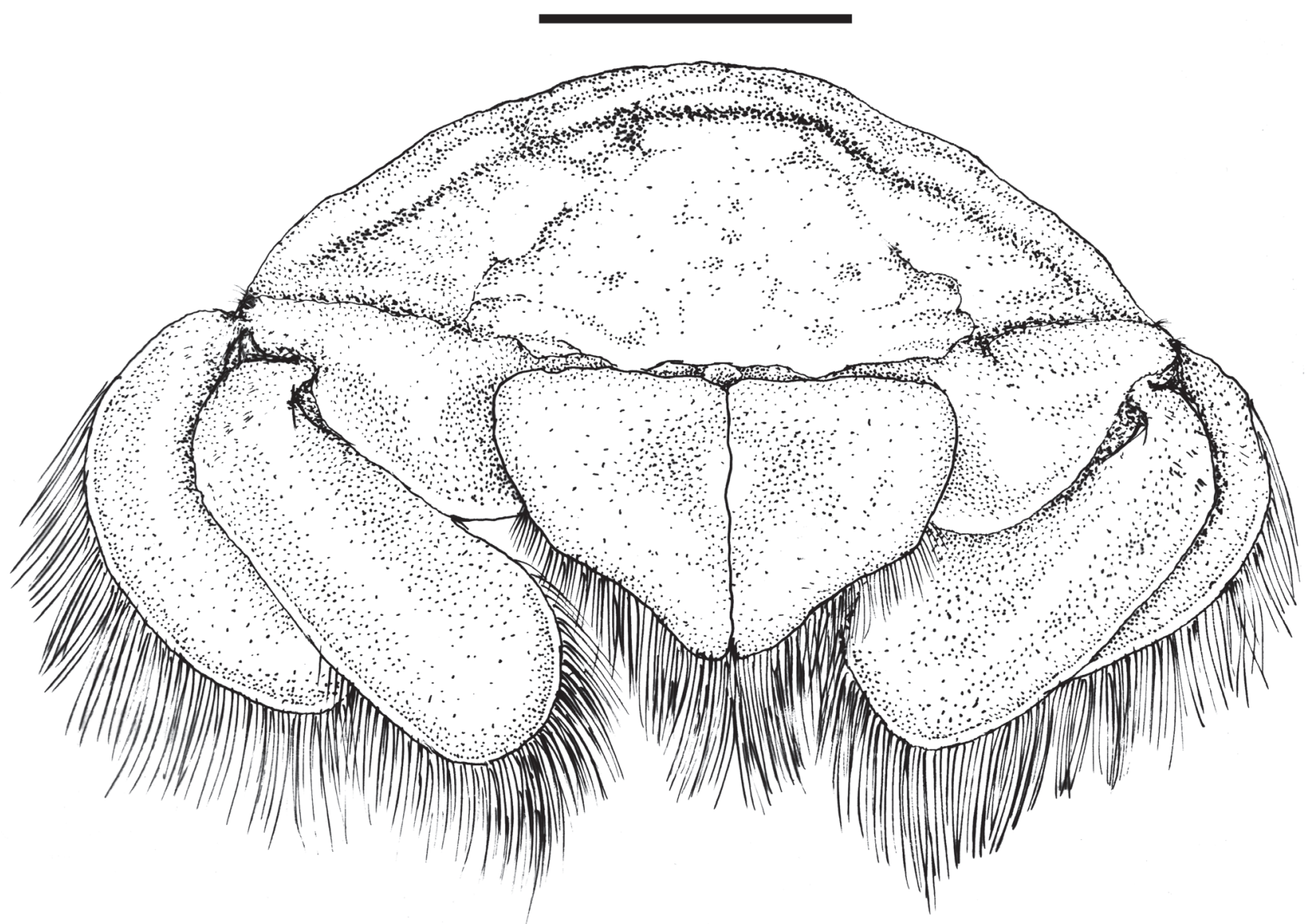

Figure 9. Aegla charon n. sp., male, holotype (MZUSP 35193), telson and uropods. Scale bar $=5.0 \mathrm{~mm}$.

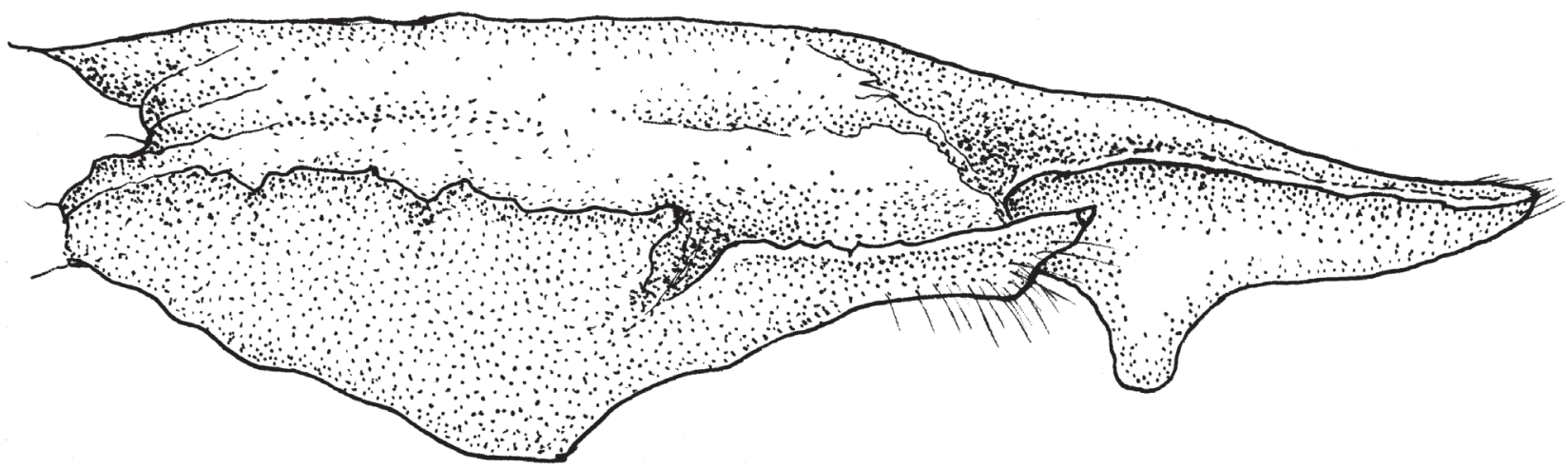

Figure 10. Aegla charon n. sp., male paratype (CL $18.11 \mathrm{~mm}$; CLR 21.46 mm) (MZUSP 35194), subrostral process. Scale bar = $5.0 \mathrm{~mm}$.

2016). So far, similar morphological condition has only been observed in the epigean species, Aegla perobae Hebling and Rodrigues, 1977 (see Fig. 13 in Moraes and Bueno, 2015).

The ontogenetic development of pleopods in aeglid females (or the lack of it in males) has not yet been properly investigated. In some Brazilian species from higher latitudes $\left(>25^{\circ} \mathrm{S}\right)$, newly-hatched juveniles lack all pairs of pleopods at birth (Bond-Buckup et al., 1996; 1999; Bueno and Bond-Buckup, 1996; Teodósio and Masunari, 2007), whereas newly-hatched juveniles of some Brazilian species from lower latitudes $\left(<25^{\circ} \mathrm{S}\right)$, pairs of pleopods $2-5$ are present as rudimentary onesegmented finger-like buds (Moraes and Bueno, 2013, 2015; Silva et al., 2017). About the latter condition, Moraes and Bueno (2013) speculated that these buds 


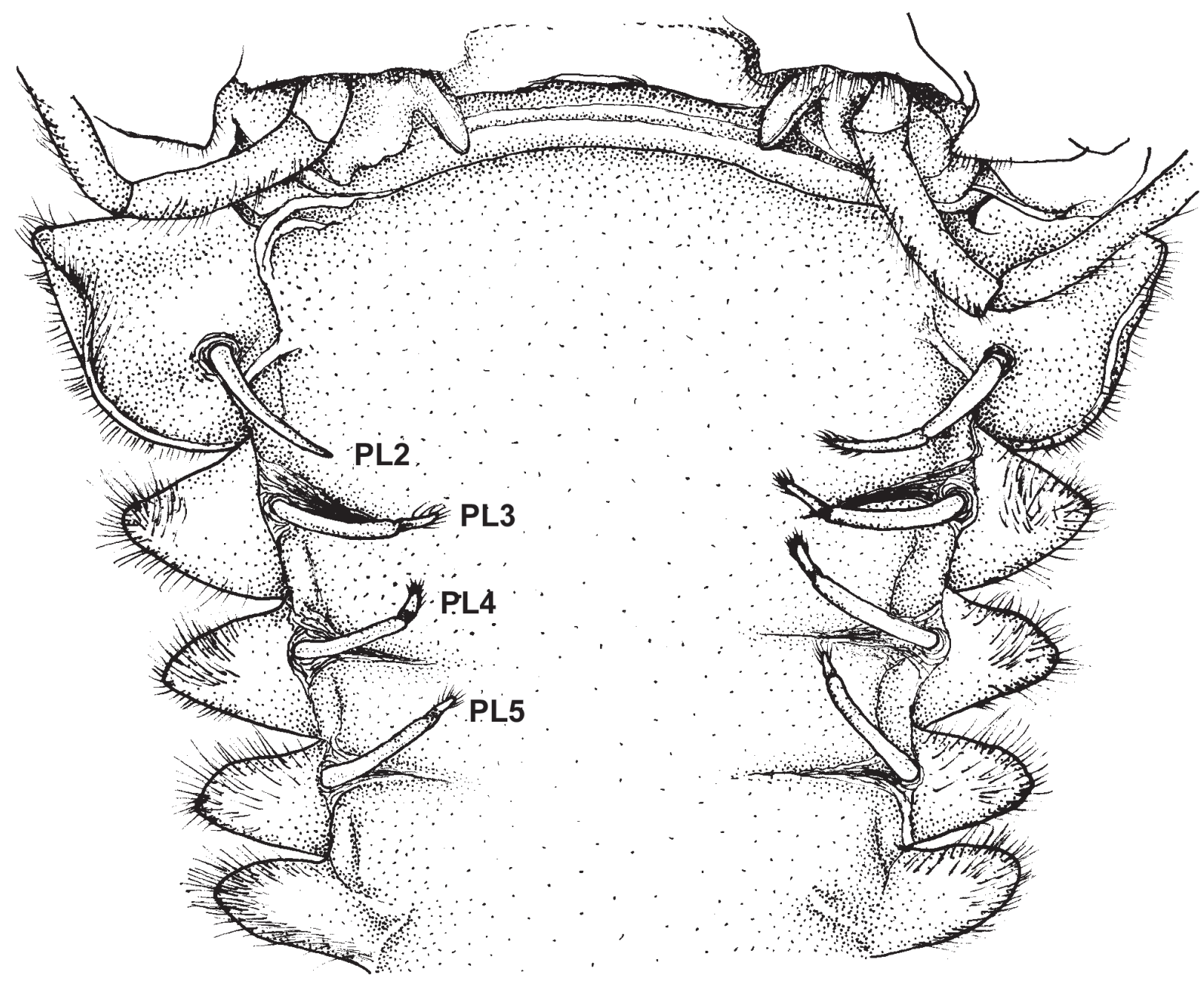

\section{$5.0 \mathrm{~mm}$}

Figure 11. Aegla charon n. sp., male paratype (CL 20.57 mm; CLR $23.95 \mathrm{~mm}$ ) (MZUSP 35194), ventral view of pleon after being streched out, showing pairs of pleopods (PL) 2 through 5. Except for one of the PL2, which is depicted as 1-segmented, all other pleopods are 2-segmented and bearing few long setae distally.

might either grow further and become fully developed later on in adult females, or regress to calcified knobs in adult males of Aegla jaragua Moraes, Tavares and Bueno, 2016 [= Aegla paulensis Schmitt, 1942 s. lat. (see Moraes et al., 2016 for details on the taxonomic rearrangement regarding the $A$. paulensis species complex)]. So far, the presence of short pleopods in males of the stygobitic $A$. charon n. sp. and of the epigean $A$. perobae, are notable exceptions that require further investigation.

The reduced pigmented area of the cornea is one of the most frequently reported troglomorphic traits associated with adaptations to obligate subterranean life in decapod crustaceans (Holthuis, 1986; Gilbert and Deharveng, 2002). In stygobitic aeglids, the size of pigmented area of the cornea may vary considerably. For simplicity, four states of relative size of cornea are herein recognized and numbered: Grade 0 - full development (= no reduction) of the pigmented area, observed in epigean and stygophilic species, such as A. perobae and A. strinatii, respectively (Fig. 12A, B); Grade 1 - slightly reduced, as observed in A. charon $\mathrm{n}$. sp. and A. leptochela (Fig. 12C, D); Grade 2 - greatly reduced, as observed in A. cavernicola (Fig. 12E); Grade 3 - complete reduction of the pigmented area of the cornea, as observed in A. microphthalma (Fig. 12F). Grades 1 through 3 are observed in stygobitic species only. 
The distributional pattern of stygobitic aeglids can be characterized as highly endemic, since their known area of occupancy is limited to subterranean habitat of the type locality and no two stygobitic species are found inhabiting the same cave. Syntopic distribution, however, have been reported between stygobitic and stygophilic species, such as the stygobitic $A$. leptochela and the stygophilic A. marginata in the "dos Paiva" cave, and between the stygobitic $A$. microphthalma and the stygophilic A. schmitti in the Santana cave (BondBuckup and Buckup, 1994; Fernandes et al., 2013; Maia et al., 2013). This is not the case of $A$. charon n. sp. since no other species of aeglid was sampled at the Lago Subterrâneo cave. Aegla charon n. sp. is also the only stygobitic aeglid species reported to inhabit lentic habitat, whilst all other species from the Alto Ribeira karst region, either from subterranean or from epigean environments, are typically found associated with lotic habitats.

Each aeglid species from the Alto Ribeira karst region can be easily separated from Aegla charon $\mathrm{n}$. sp. by the combination of specific morphological characters, as follows.

Aegla microphthalma can be separated from $A$. charon $n$. sp. by the: (i) lack of pigmented area of the cornea (grade 3); (ii) subrostral process absent; (iii) ventral margin of pleonal epimera 3 and 4 armed with corneous scale; (iv) anteromesial sclerite of third sternite regressive; (v) sexual tube short.

Aegla leptochela can be distinguished from $A$. charon n. sp. by the following traits: (i) orbital spines absent or rudimentary; (ii) interior branchial area uniform, with no distinction between an elevated inner half area and a depressed outer half area; (iii) palmar crest of minor chela rudimentary; (iv) distal portion of subrostral process acute and curved anteriorly; (v) rostrum short (wide base triangular shaped).

Aegla cavernicola differs from $A$. charon $\mathrm{n}$. $\mathrm{sp}$. in that: (i) its pigmented area of cornea is greatly reduced (grade 2); (ii) epigastric prominences are rudimentary; (iii) palmar crest of minor chela is disciform; (iv) proximal lobe on dorsal margin of dactylus of both chelae is absent; (v) subterminal lobe on dorsal margin of carpus of both chelipeds is rudimentary; (vi) anterolateral lobe straight is not curved upward distally.

Aegla strinatii can be separated from $A$. charon $\mathrm{n}$. sp. by the following combination of characters: (i) no reduction of pigmented area of cornea (grade 0); (ii) limits between dorsum of second hepatic lobe and dorsum of gastric area well marked; (iii) subterminal lobe on dorsal margin of carpus of both chelipeds rudimentary; (iv) subrostral process spiniform and oriented anteriorly; (v) interior branchial area uniform, with no distinction between an elevated inner half area and a depressed outer half area.

The A. schmitti population from Alto Ribeira karst area can be separated from $A$. charon $\mathrm{n}$. sp. in having: (i) no reduction of pigmented area of cornea (grade 0 ); (ii) palmar crest of minor chela markedly disciform; (iii) carpal crest devoid of tubercles; (iv) subterminal lobe on dorsal margin of carpus of both chelipeds rudimentary (v) ventral margin of pleonal epimera 2 , 3 and 4 armed with corneous scale.

The A. marginata population from Alto Ribeira karst area can be distinguished from $A$. charon $n$. sp. by the following combination of character: (i) no reduction of pigmented area of cornea (grade 0); (ii) palm of major chela high; (iii) palmar crest of major chela rudimentary; (iv) sexual tube short; (v) protogastric lobes pronounced with a set of corneous scales.

Though the epigean $A$. perobae and stygobitic A. charon n. sp. share the presence of short, twosegmented in some pleopods in males specimens, each species is endemic to entirely different and disjunctive hydrographic basins: the Tietê Basin and the Ribeira de Iguape Basin (Alto Ribeira karst region), respectively. Nevertheless, the former species can be easily set apart from the latter by the following combination of characters: (i) proximal lobe on dorsal margin of dactylus absent; (ii) rostral carina not elevated at medium-third; (iii) distal end of rostrum straight, not curved upward; (iv) epigastric prominences rudimentary; (v) anteromesial sclerite of third sternite regressive; (vi) margin of palmar crest of major chela rather regular, lacking row of clearly defined tubercles or spines; (vii) interior branchial area uniform, with no distinction between an elevated inner half area and a depressed outer half area.

Remarks on conservation status. We suggest that $A$. charon n. sp. be assigned as "Critically Endangered "(CR) under criteria B2ab(iii) as defined by the IUCN Red List Categories and Criteria (IUCN Standards and Petitions Subcommittee, 2016). The suggested conservation category is based on the highly endemic 


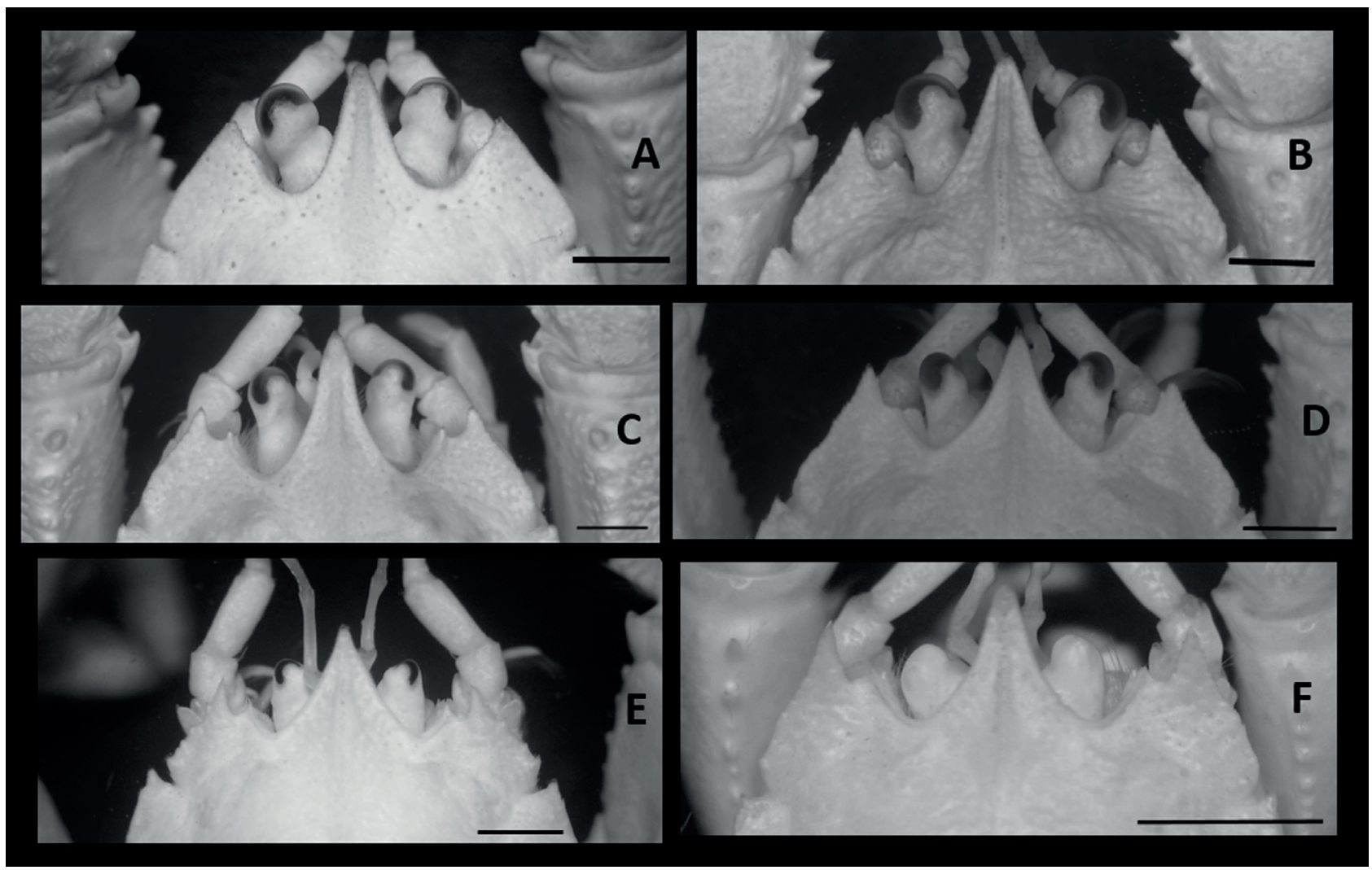

Figure 12. Distal portion of anterior region of carapace showing relative difference in size of pigmented area of cornea among aeglids: Grade 0 (fully developed) in the epigean species Aegla perobae (A) and in the stygophilic species A. strinatii (B). Grade 1 (slightly reduced) in the stygobitic species A. charon n. sp. (C), and A. leptochela (D). Grade 2 (greatly reduced) in the stygobitic species A. cavernicola (E). Grade 3 (absent) in the stygobitic species A. microphthalma (F). All species are endemic to Alto Ribeira karst region, except $A$. perobae, which is endemic to the Tietê Hydrographic Basin. Scale bars $=2.0 \mathrm{~mm}$.

distribution pattern of the species, restricted to one single location (= type locality) and with an area of occupancy estimated to be significantly less than $10 \mathrm{~km}^{2}$ of fragile habitat.

Subterranean ecosystems are very unique and intrinsically fragile; the food web in this ever-darkened environment is truncated, characterized by the absence of primary producers and primary consumers, and strongly dependent on allochthonous resources of energy (Trajano, 2000; Gilbert and Deharveng, 2002). Subterranean environments are therefore highly influenced by disturbances from epigean world (Trajano, 2000), let alone man-made disturbances. The Alto Ribeira karst area is still impacted by environmental interference caused by human activities, such as limestone quarrying, deforestation, pollution and siltation of rivers that feed subterranean systems (Trajano, 2000). Mining, touristic disturbances and decline in habitat quality, for instance, were reported as possible causes for the observed reduction in the population size of the highly endemic stygobitic aeglids (A. microphthalma, A. cavernicola and A. leptochela) in their respective type localities (Moracchioli, 1994; Maia et al., 2013). The Alto Ribeira karst area is a hotspot for a barely explored cave fauna diversity, and still holds great taxonomic hidden treasures yet to be discovered and properly documented. 


\section{Key to species of aeglids from the Alto Ribeira karst region}

1. Pigmented area of cornea reduced (grades 1 or 2) or absent (grade 3). Stygobitic species ..................... 2

- $\quad$ Pigmented area of cornea not reduced (grade 0). Stygophilic or epigean species ...................................... 5

2(1) Pigmented area of cornea reduced ( 1 or 2 ). Subrostral process present. Anteromesial margin of third thoracic sternite abrupt or truncate

Pigmented area of cornea absent (grade 3). Subrostral process absent. Anteromesial margin of third thoracic sternite tapered Aegla microphthalma

3(2) Pigmented area reduced (grade 1). Epigastric prominences conspicuous. Protogastric lobes rudimentary. Palmar crest of minor chela rectangular .

- Pigmented area reduced (grade 2). Epigastric prominences rudimentary. Protogastric lobes absent. Palmar crest of minor chela disciform Aegla cavernicola

4(3) Rostrum narrow base triangular shaped. Subrostral process broad, subrectangular or triangular shaped, apex blunt. Orbital spine well developed. Posterolateral margin of telson concave mesially. Variable number of short two-segmented uniramous pleopods in male specimens Aegla charon n. sp. Rostrum broad base triangular shaped. Subrostral process acute and oriented anteriorly. Orbital spine greatly reduced or absent. Posterolateral margin of telson straight mesially. Pleopods absent in male specimens Aegla leptochela

5(1) Sexual tube short and wide. Protogastric lobes prominent. Posterolateral margin of telson straight mesially Aegla marginata Sexual tube long and narrow. Protogastric lobes rudimentary or absent. Posterolateral margin of telson concave mesially.

6(5) Subrostral process broad, apex blunt. Anterolateral angle of second epimera armed with spiniform corneous scale. Mid-anterior region of fourth sternite with one or two spiniform corneous scales sub-distally ..... Aegla schmitti Subrostral process spiniform and oriented anteriorly. Anterolateral angle of second epimera unarmed. Mid-anterior region of fourth sternite unarmed .... Aegla strinatii

\section{ACKNOWLedgementS}

This paper is dedicated to the late Dr. Michael Türkay who was the first decapod investigator ever to describe a stygobitic (Aegla cavernicola) and a stygophilic (Aegla strinatii) species of aeglids. Our sincere thankfulness to "Grupo Bambuí de Pesquisas Espeleológicas", a professional Brazilian speleological research group, which secured all safety and working conditions during the exploration of the "Lago Subterrâneo" cave. Special thanks to my daughter, Adriana Passos Bueno - Yes, that is her with me in Fig. 3, during our visual search for aeglids -, who boldly and gracefully accompanied me (SLSB) and the Bambuí group in our long and memorable journey to the subterranean world and who was responsible for the successful capturing of some of the specimens of the new species. Thanks also to Emerson Ramos Nogueira for the scientific illustrations of the new species. We are also much grateful for the financial support provided by the Fundação de Amparo à Pesquisa do Estado de São Paulo (Grant No. 2008/57128-0). Thanks to Tessa Bueno for reviewing the English text.

\section{References}

Baldari, F.; Mejía-Ortíz, L.M. and López-Mejía, M. 2010. A new cave species of Cryphiops (Crustacea: Decapoda: Palaemonidae) from southern Mexico. Zootaxa, 2427: 47-54.

Bond-Buckup, G. and Buckup, L. 1994. A Família Aeglidae (Crustacea, Decapoda, Anomura). Arquivos de Zoologia, 32: $1-346$.

Bond-Buckup, G.; Bueno, A.A.P. and Keunecke, K.A. 1996. Primeiro estágio juvenil de Aegla prado Schmitt (Crustacea, Decapoda, Anomura, Aeglidae). Revista brasileira de Zoologia, 13: 1049-1061.

Bond-Buckup, G.; Bueno, A.P. and Keunecke, K.A. 1999. Morphological characteristics of juvenile specimens of 
Aegla (Decapoda, Anomura, Aeglidae).p. 371-381. In: F. R. Schram and J.C. von Vaupel Klein (eds.), Crustaceans and the Biodiversity Crisis: Proceedings of the Fourth International Crustacean Congress, Amsterdam, The Netherlands, July, 20-24, 1998, vol. 1. Leiden, Brill.

Botosaneanu, L. 1986. Stygofauna Mundi. A Faunistic, Distribution, and Ecological Synthesis of the World Fauna Inhabiting Subterranean Waters (Including the Marine Insterstitial). Leiden, Brill/Backhuys, 740p.

Bueno, A.A.P. and Bond-Buckup, G. 1996. Os estágios juvenis de Aegla violacea Bond-Buckup and Buckup (Crustacea, Anomura, Aeglidae). Nauplius, 4: 39-47.

Bueno, S.L.S.; Shimizu, R.M. and Moraes, J.C.B. 2016. A Remarkable Anomuran: The taxon Aegla Leach, 1820. Taxonomic remarks, distribution, biology, diversity and conservation. Cap. 2: p. 23-64. In: T. Kawai and N. Cumberlidge, (eds.), A Global Overview of the Conservation of Freshwater Decapod Crustaceans. Cham, Switzerland: Springer International Publishing AG.

Cai, Y. and Vidthayanon, C. 2016. Macrobrachium spelaeus, a new species of stygobiotic freshwater prawn from Thailand (Decapoda: Palaemonidae). Raffles Bulletin of Zoology, 64: 117-122.

Christman, M.C. and Culver, D.C. 2001. The relationship between cave biodiversity and available habitat. Journal of Biogeography, 28: 367-380.

Culver, D.C. and Sket, B. 2000. Hotspots of subterranean biodiversity in caves and Wells. Journal of Cave and Karst Studies, 62: 11-17.

Fernandes, C.S.; Bueno, S.L.S. and Bichuette, M.E. 2013. Distribution of cave-dwelling Aegla spp. (Decapoda: Anomura: Aeglidae) from the Alto Ribeira karstic area in southeastern Brazil, based on geomorphological evidence. Journal of Crustacean Biology, 33: 567-575.

Gilbert, J. and Deharveng, L. 2002. Subterranean ecosystems: a truncated functional biodiversity. BioScience, 52: 473-481.

Graening, G.O. and Fenolio, D.B. 2005. Status of the Delaware county cave crayfish, Cambarus subterraneus (Decapoda: Cambaridae). Proceedings of the Oklahoma Academy of Sciences, 85: 85-89.

Hobbs Jr, H.H.; Hobbs III, H.H. and Daniel, M.A. 1977. A review of the troglobitic decapods crustaceans of the Americas. Smithsonian Contributions to Zoology, 244: 1-183.

Holthuis, L.B. 1986. Decapoda. p. 589-615. In: L. Botosaneanu (ed.), Stygofauna Mundi. A Faunistic, Distribution, and Ecological Synthesis of the World Fauna Inhabiting Subterranean Waters (Including the Marine Insterstitial). Leiden, Brill/Backhuys.

IUCN Standards and Petitions Subcommittee. 2016. Guidelines for Using the IUCN Red List Categories and Criteria. Version 12. Prepared by the Standards and Petitions Subcommittee. Available at http://www.iucnredlist.org/documents/ RedListGuidelines.pdf. Accessed on 23 December 2016

Maia, K.P.; Bueno, S.L.S. and Trajano, E. 2013. Ecologia populacional e conservação de eglídeos (Crustacea: Decapoda: Aeglidae) em cavernas da área cárstica do Alto Ribeira, em São Paulo. Revista da Biologia, 10: 40-45.

Marin, I. and Sokolova, A. 2014. Redescription of the stygobiotic shrimp Troglocaris (Xiphocaridinella) jusbaschjani Birštein,
1984 (Decapoda: Caridea: Atyidae) from Agura River, Sochi, Russia, with remarks on other representatives of the genus from Caucasus. Zootaxa, 3754: 277-298.

Martin, J.W. and Abele, L.G. 1988. External morphology of the genus Aegla (Crustacea: Anomura: Aeglidae). Smithsonian Contributions to Zoology, 453: 1-46.

Mejía-Ortíz, L.M.; Baldari, F. and López-Mejía, M. 2008. Macrobrachium sbordonii (Decapoda: Palaemonidae), a new stygobitic species of freshwater prawn from Chiapas Mexico. Zootaxa, 1814: 49-57.

Mejía-Ortíz, L.M.; Hartnoll, R.G. and Viccon-Pale, J.A. 2003. A new stygobitic crayfish from Mexico, Procambarus cavernicola (Decapoda: Cambaridae), with review of cave-dwelling crayfishes in Mexico. Journal of Crustacean Biology, 23: 391-401.

Moracchioli, N. 1994. Estudo da Biologia de Aegla spp. Cavernícolas do Vale do Alto Ribeira, São Paulo (Crustacea: Anomura: Aeglidae). Instituto de Biociências - Universidade de São Paulo - USP, Master Dissertation, 148p. [Unpublished].

Moraes,J.C.B. and Bueno, S.L.S. 2013. Description of the newlyhatched juvenile of Aegla paulensis (Decapoda, Anomura, Aeglidae). Zootaxa, 3635: 501-519.

Moraes, J.C.B. and Bueno, S.L.S. 2015. Description of the newlyhatched juvenile of Aegla perobae (Crustacea: Decapoda: Aeglidae). Zootaxa, 3973: 491-510.

Moraes, J.C.B.; Terossi, M.; Buranelli, R.C.; Tavares, M.; Mantelatto, F.L. and Bueno, S.L.S. 2016. Morphological and molecular data reveal the cryptic diversity among populations of Aegla paulensis (Decapoda, Anomura, Aeglidae), with descriptions of four new species and comments on dispersal routes and conservation status. Zootaxa, 4193: 1-48.

Pires, A.M.S. 1987. Potiicoara brasiliensis: a new genus and species of Spelaeogriphacea (Crustacea: Peracarida) from Brazil with a phylogenetic analysis of the Peracarida. Journal of Natural History, 21: 225-238.

Rocha, S.S. and Bueno, S.L.S. 2004. Crustáceos decápodes de água doce com ocorrência no Vale do Ribeira de Iguape e rios costeiros adjacentes, São Paulo, Brasil. Revista brasileira de Zoologia, 21: 1001-1010.

Rocha, S.S. and Bueno, S.L.S. 2011. Extension of the known distribution of Aegla strinatii Türkay, 1972 and a checklist of decapod crustaceans (Aeglidae, Palaemonidae and Trichodactylidae) from the Jacupiranga State Park, south of São Paulo State, Brazil. Nauplius, 19: 163-167.

Schmitt, W.L. 1942. The species of Aegla, endemic South American fresh-water crustaceans. Proceedings of the United States National Museum, 91: 431-520.

Silva, L.S.A., Guerrero-Ocampo, C.M., Negreiros-Fransozo, M.L. and Teixeira, G.M. 2017. Description of the newly-hatched juvenile of Aegla castro Schmitt, 1942 (Crustacea, Anomura, Aeglidae). Zootaxa, 4237: 167-180.

Sket, B. 1999. The nature of biodiversity in hypogean waters and how it is endangered. Biodiversity and Conservation, 8: 1319-1338.

Stoch, F. 1995. The ecological and historical determinants of crustacean diversity in groundwaters, or: why are there so many species? Mémoires de Biospéologie, 22: 139-160. 
Teodósio, E.A.F.M.O. and Masunari, S. 2007. Description of first two juvenile stages of Aegla schmitti Hobbs III, 1979 (Anomura: Aeglidae). Nauplius, 15: 73-80.

Trajano, E. 2000. Cave faunas in the Atlantic Tropical Rain Forest: composition, ecology, and conservation. Biotropica, 32: 882-893.
Türkay, M. 1972. Neue Höhlendekapoden aus Brasilien (Crustacea). Revue Suisse de Zoologie, 79: 415-418.

Villalobos, J.L. and Álvarez, F. 2013. Two new genera and three new species of freshwater crabs (Crustacea: Pseudothelphusidae: Potamocarcinini) from Chiapas, Mexico. Zootaxa, 3599: 457-470. 